\title{
DESAIN LERENG FINAL DENGAN METODE RMR, SMR DAN \\ ANALISIS KESTABILAN LERENG: \\ PADA TAMBANG BATUBARA TERBUKA, DI KABUPATEN TANAH LAUT, PROVINSI KALIMANTAN SELATAN
}

\author{
FINAL SLOPE DESIGN USING RMR, SMR AND \\ SLOPE STABILITY ANALYSIS METHODS: \\ AT COAL OPEN PIT, TANAH LAUT REGENCY, \\ SOUTH KALIMANTAN PROVINCE
}

\author{
Oleh: \\ Galih W. Swana, Dicky Muslim, Irvan Sophian \\ Fakultas Geologi, Universitas Padjadjaran \\ Jalan Raya Bandung Sumedang KM.21 Jatinangor 45363
}

\section{SARI}

Dalam menentukan kemiringan desain final lereng yang dibentuk, salah satu caranya ialah dengan menggunakan metode geomekanik melalui penentuan nilai Rock Mass Rating (RMR) dan nilai Slope Mass Rating (SMR). Namun, dari nilai SMR tidak diketahui faktor keamanan dari lereng tersebut sehingga diperlukan analisis kestabilan lereng. Nilai kemiringan lereng dan faktor keamanannya dapat menjadi acuan untuk membuat desain lereng final yang representatif.

Penelitian dilakukan di tambang terbuka yang terdapat di Kecamatan Jorong Kabupaten Tanah Laut, Provinsi Kalimantan Selatan. Daerah penelitian terletak pada Formasi Warukin dengan unit stratigrafinya yaitu batupasir (pasir kasar - halus), mudstone dan carbonaceous mudstone, serta batubara dengan jurus $\mathrm{N} 80^{\circ}-90^{\circ} \mathrm{E}$ dan kemiringan $29^{\circ}-35^{\circ}$. $R M R$ pada section Sidewall berkisar antara 25- 59, dan SMR berkisar antara $30,1^{\circ}-59^{\circ}$; pada section Western Lowwall atau data bor AGT-02 dan AGT-03 berkisar antara 20 - 55 dan SMR berkisar antara $20^{\circ}-55^{\circ}$. Pada section Western Highwall RMR berkisar antara $34-71$ dan SMR berkisar antara 33,06 $-71^{\circ}$. Pada section Eastern Lowwall RMR berkisar antara 20 - 55 dan SMR berkisar antara $20^{\circ}-$ $54,96^{\circ}$. Pada section Eastern Highwall RMR berkisar antara 29 - 79 dan SMR berkisar antara $29^{\circ}-52^{\circ}$.

Dari hasil analisis kestabilan lereng, pada umumnya nilai kemiringan lereng hasil dari nilai SMR berada pada kondisi labil sampai stabil sehingga perlu dilakukan penurunan muka air tanah pada beberapa bagian agar dihasilkan desain final lereng yang stabil.

Kata Kunci : Geomekanika, analisis kestabilan lereng, desain lereng final

\section{ABSTRACT}

In determining the slope of the final design of formed slopes, one of the way is by using the method of geomechanic that determining value through Rock Mass Rating (RMR) and the Slope Mass Rating (SMR). However, from the SMR value the safety factor of the slope is unknown, so that the slope stability analysis is required. Slope value and the safety factor can be used as a reference to create the final design of representative slopes.

This research was conducted in Jorong District, Tanah Laut Regency, South Kalimantan Province. Morphology in the research area is slightly flat because it is not far from the beach in 
the south side, where the northern side is a production forest. The research area lies on the Warukin Formation, which consists of sandstone (coarse to fine sand), mudstone , carbonaceous mudstone, and coal bed with strike $N 80^{\circ}-90^{\circ} \mathrm{E}$ and dip $29^{\circ}-35^{\circ}$. RMR in the Sidewall section ranges between 25-59, and the SMR ranged between $30.1^{\circ}-59^{\circ}$; on the Western Lowwall section or drill data of AGT-02 and AGT-03 RMR ranged between 20-55 and the SMR ranged between $20^{\circ}-55^{\circ}$. In Western Highwall section RMR ranged between $34-71$ and the SMR ranged between $33.06^{\circ}-71^{\circ}$. In the Eastern Lowwall section RMR ranged between 20-55 and the SMR ranged between $20^{\circ}-54.96^{\circ}$. In the Eastern Highwall section of RMR ranged between 29-79 and the SMR ranged between $29^{\circ}-52^{\circ}$.

The result of slope stability analysis shows that slope of SMR values are in unstable to stable condition, therefore it is necessary to reduce the groundwater level to obtain a stable final slope design.

Keywords : Geomechanics, slope stability analysis, final slope design

\section{PENDAHULUAN}

Dalam penambangan terbuka (open pit mining), desain lereng final adalah salah satu faktor terpenting dalam keberlangsungan pertambangan. Beberapa cara yang dilakukan untuk membuat suatu desain final diantaranya dengan analisis geomekanika dan analisis kestabilan lereng. Analisis geomekanika diantaranya mencakup kegiatan pengeboran dan uji laboratorium untuk mendapatkan data parameter fisik dan kekuatan batuan yang dibutuhkan untuk mengetahui deskripsi massa batuan (Sjoberg, 1997). Sedangkan untuk mendapat desain lereng tambang, diperlukan data lapangan, baik berupa morfologi setempat, jurus-kemiringan dan jenis batuan, kondisi airtanah, dan lainnya, yang diperlukan untuk simulasi kestabilan lereng.

Data geotechnical drilling log diambil dan diuji di laboratorium mekanika batuan guna mendapatkan parameter kekuatan fisik yang dibutuhkan untuk mendapatkan klasifikasi massa batuan yang akan memperhitungkan kondisi stabil dari setiap jumlah kelas massa batuan yang dideskripsi dengan mengukur Unconfined Compressive Strength (UCS), Rock Quality Designation $(R Q D)$ (Bienawski, 1989) dan identifikasi diskontinuitas dari batuan serta kondisi air tanah pada sample core.

Dalam penentuan klasifikasi masa batuan digunakan penghitungan Rock Mass Rating (RMR) (Bieniawski, 1989), kemudian dari hasil pembobotan nilai $R M R$ diperoleh sudut maksimum pemotongan lereng (slope) suatu masa batuan dalam keadaan stabil dengan menghitung nilai Slope Mass Rating $(S M R)$. Namun nilai $S M R$ belum memberikan nilai keamanan dari suatu lereng, maka diperlukan analisis kestabilan lereng.

Penelitian dilakukan di Kecamatan Jorong, Kabupaten Tanah Laut, Provinsi Kalimantan Selatan, utamanya berada di daerah $Y$ yang tersusun oleh pit 1 dan pit 2 . Morfologi daerah ini berupa pedataran landai yang tidak jauh dari garis pantai di sebelah selatan. Di sebelah utara terdapat hutan dengan berbagai macam tumbuhan berukuran kecil ataupun besar.

Maksud penelitian ini adalah untuk mengetahui desain lereng tambang final berdasarkan nilai SMR. Untuk mencapai tujuan tersebut dilakukan klasifikasi massa batuan berdasarkan karakteristik geomekanik $(R M R)$, kemudian mengetahui nilai sudut yang dibentuk dari massa batuan tersebut $(S M R)$, setelah itu dilakukan analisis kestabilan lereng untuk mengetahui nilai Factor of Safety (FS) dengan bantuan software Slope/W 2004 untuk kemudian dibuat desain lereng final yang representatif di daerah penelitian.

\section{KAJIAN PUSTAKA \\ Geologi Regional}

Daerah penelitian termasuk dalam Subcekungan Asam-Asam sebagai bagian dari Cekungan Barito dan masuk ke dalam Formasi Warukin (Gambar 1).

Daerah penelitian terdiri dari 


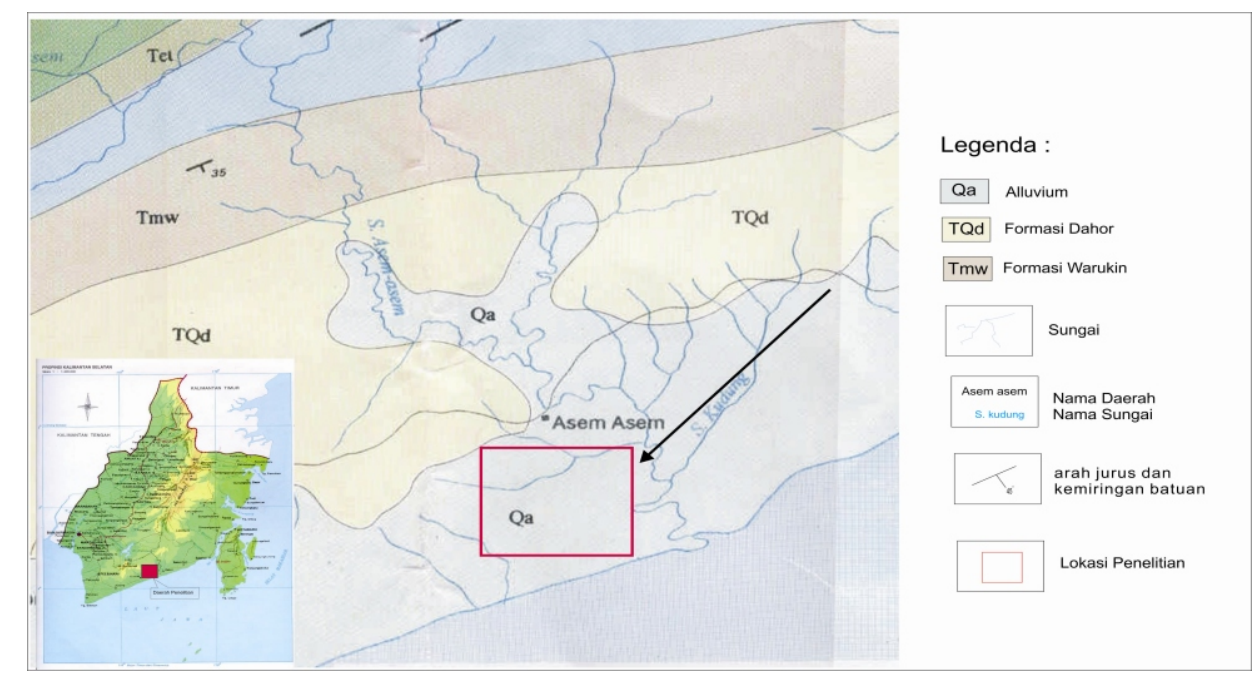

Gambar 1. Peta geologi regional daerah penelitian (Sikumbang dan Heryanto, 1994)

perselingan batupasir kuarsa, batulempung, serpih, dan batugamping. Pada batupasir dan batulempung karbonatan sering dijumpai konkresi besi. Lapisan batubara memiliki tebal > 25 meter, berwarna hitamabuabu, getas, kurang padu, yang dikenal sebagai Formasi Warukin. Tebal batuan Formasi Warukin antara 250 - 750 meter, diperkirakan berumur Miosen Tengah Miosen Akhir. (Sikumbang dan Heryanto, 1994)

\section{Klasifikasi RMR}

Klasifikasi geomekanik sistem $R M R$ adalah suatu metode empiris untuk menentukan pembobotan dari suatu massa batuan, digunakan untuk mengevaluasi ketahanan massa batuan sebagai salah satu cara untuk menentukan kemiringan lereng maksimum (Bieniawski, 1989). Klasifikasi ini didasarkan pada enam parameter yaitu kekuatan batuan (rock strength), Rock Quality Designation (RQD), jarak diskontinuitas (spacing of discontinuities), kondisi diskontinuitas (condition of discontinuities), kondisi airtanah (groundwater condition), dan orientasi diskontinuitas (orientation of discontinuities).

\section{Penentuan Nilai SMR}

Untuk menentukan geometri lereng yang terbentuk dapat dilakukan dengan metode SMR dalam hal ini adalah metode Romana (1993) dengan formula :

\footnotetext{
$S M R=R M R-(F 1 \times F 2 \times F 3)+F 4$

Keterangan :

$\mathrm{F} 1$ = rata-rata strike dari joint dikurangi slope strike

$\mathrm{F} 2$ = rata-rata dip dari joint

$\mathrm{F} 3$ = rata-rata dip dari joint dikurangi sudut slope

Nilai F4 ditentukan berdasarkan metode ekskavasinya.
}

\section{Metode Limit Equilbrium dalam Pemodelan Slope/W 2004}

Software Slope/W 2004 menggunakan metode limit equlibrium ( $L E)$ yang telah umum digunakan untuk menganalisis stabilitas lereng. Pada metode ini diasumsikan terdapat bidang gelincir yang potensial, dimana kondisi gaya (force) dan moment equilibrium ditentukan berada pada kondisi statis. Analisis ini membutuhkan informasi tentang kekuatan material.

Secara garis besar analisis ini menghasilkan keluaran berupa Factor of Safety (Eberhardt, 2005), dimana rumus sederhana dalam limit equilibrium ini adalah :

FS $=\frac{\text { Resisting Force }}{\text { Driving Force }} \quad$ atau $\quad$ FS $=\frac{\text { Shear Strength }}{\text { Shear Stress }}$

Resisting force atau gaya penahan adalah gaya yang bekerja relatif berlawanan terhadap arah gaya penggerak umumnya dipengaruhi oleh jenis batuan dan kekuatan batuan itu sendiri. Sedangkan Driving Force 
atau gaya penggerak ialah gaya yang bekerja berlawanan terhadap gaya penahan umumnya dipengaruhi oleh diskontinuitas dari batuan, gaya gravitasi, kemiringan lereng, dan sebagainya (Eberhardt, 2005).

\section{Sifat Fisik dan Mekanik}

Sifat-sifat fisik batuan yang digunakan dalam simulasi dan mempengaruhi kestabilan lereng diantaranya adalah; berat isi batuan ( $\mathrm{\gamma}$ ), kadar air dalam batuan $(\omega)$, kohesi batuan (c) dan sudut geser dalam batuan $\left({ }^{\circ}\right)$. Sudut geser dalam adalah sudut yang dibentuk dari hubungan antara tegangan normal dan tegangan geser dalam suatu batuan ataupun tanah. Semakin besar sudut geser dalamnya, maka material tersebut semakin besar tahanannya terhadap tegangan luar yang diterimanya. Untuk penelitian ini penulis menggunakan bantuan software Roclab 1.0. untuk menentukan nilai sudut geser dalam.

\section{Factor of Safety (FS)}

Menurut Bowles (1984), apabila harga FS untuk suatu lereng $>1,25$ yang berarti gaya penahan lebih besar daripada gaya penggerak, maka lereng tersebut berada dalam keadaan stabil. Tetapi, bila nilai $F S<$ 1,07 yang artinya gaya penahan lebih kecil daripada gaya penggerak, maka lereng tersebut berada dalam keadaan tidak stabil dan rawan terjadi longsor. Akan tetapi, jika nilai kestabilan lerengnya 1,07 $<F S<1,25$ maka lereng tersebut berada dalam keadaan kritis.

Bowles (1984) juga menyatakan bahwa kondisi $1,07<F S<1,25$ tetap tidak dikehendaki, karena apabila terjadi pengurangan gaya penahan atau penambahan gaya penggerak sekecil apapun, lereng akan menjadi tidak stabil dan rawan terjadi longsor. Oleh karena itu, nilai FS selalu dibuat lebih dari 1,25.

\section{METODOLOGI}

Studi lapangan yang dilakukan ialah berupa pemetaan geologi teknik dan pengamatan geotechnical drilling log untuk mengetahui beberapa parameter geoteknik seperti jenis litologi, strength dari material, tingkat pelapukan, tipe dan bentuk diskontinuitas serta GSI (Geological Strength Index) sebagai parameter untuk melakukan pemodelan desain lereng tambang.

Kemudian dilakukan pengumpulan data geomekanik untuk memperoleh gambaran awal mengenai kondisi massa batuan dengan menggunakan klasifikasi geomekanik sistem $R M R$, dengan cara :

1. Menjumlahkan nilai bobot dari parameter $U C S, R Q D$, jarak diskontinuitas, kondisi diskontinuitas, dan kondisi airtanah, sehingga diperoleh nilai $R M R$ dasar.

2. Menentukan nilai RMR terkoreksi dengan cara menjumlahkan nilai bobot dari langkah pertama dan kedua, kemudian menentukan kelas massa batuan berdasarkan nilai $R M R$ terkoreksi.

3. Menentukan nilai $S M R$ dengan mengambil parameter - parameter terkait yaitu strike dan dip dari joint serta dari slope.

4. Dengan rumus $S M R$ diakumulasikan dengan nilai $R M R$ sehingga diperoleh nilai SMR yang akan digunakan di tiap section.

5. Geometri lereng final mengacu kepada nilai SMR menurut Romana (1993), dengan membuat overall slope berdasarkan nilai rata - rata SMR dan nilai SMR terkecil dikarenakan nilai ratarata dan nilai $S M R$ terkecil tersebut dianggap sudah mewakili dari semua nilai SMR yang ada.

6. Kemudian dengan menggunakan bantuan Software Roclab 1.0 didapat nilai kohesi (c) dan nilai sudut geser dalam, dan mengkorelasinya dengan hasil data laboratorium mekanika batuan.

7. Melakukan analisis kestabilan lereng menggunakan software Slope/W 2004 untuk diperoleh nilai Factor of Safety. Simulasi kestabilan lereng dilakukan 3 kali yaitu, analisis dalam keadaan non saturated, saturated tanpa pengaruh gempa, dan saturated dengan pengaruh koefisien gempa. Berdasarkan data kegempaan regional Provinsi Kalimantan Selatan yang memiliki Seismic load horisontal sebesar 0.01 dan vertikal sebesar 0.005 .

\section{HASIL DAN PEMBAHASAN Geologi Teknik} Hasil uji Direct Shear pada sample 
Tabel 1.

Sifat mekanik batuan pada daerah penelitian

\begin{tabular}{|c|l|l|l|l|l|}
\hline No. & \multicolumn{1}{|c|}{ Material } & $\begin{array}{c}\gamma_{\text {dry }} \\
(\mathbf{k N / m 3 )}\end{array}$ & $\begin{array}{c}\gamma_{\text {sat }} \\
(\mathbf{k N / m 3 )}\end{array}$ & \multicolumn{1}{c|}{$\mathbf{c}(\mathbf{k P a})$} & \multicolumn{1}{|c|}{} \\
\hline 1 & Mudstone & 18 & 20.34 & $101-249$ & $17.11-31.5$ \\
\hline 2 & Carbonaceous Mudstone & 18.6 & 21.018 & $45-148$ & $9.01-21.85$ \\
\hline 3 & Batupasir & 17.9 & 20.94 & $130.3-550$ & $21-46.37$ \\
\hline 4 & Batubara & 13.5 & 20.115 & $130-464$ & $25.46-48.42$ \\
\hline
\end{tabular}

Keterangan:

ydry= Bobot isi kering

ysat $=$ Bobot isi jenuh

$\mathrm{c}=$ Kohesi

$\varphi=$ Sudut geser dalam
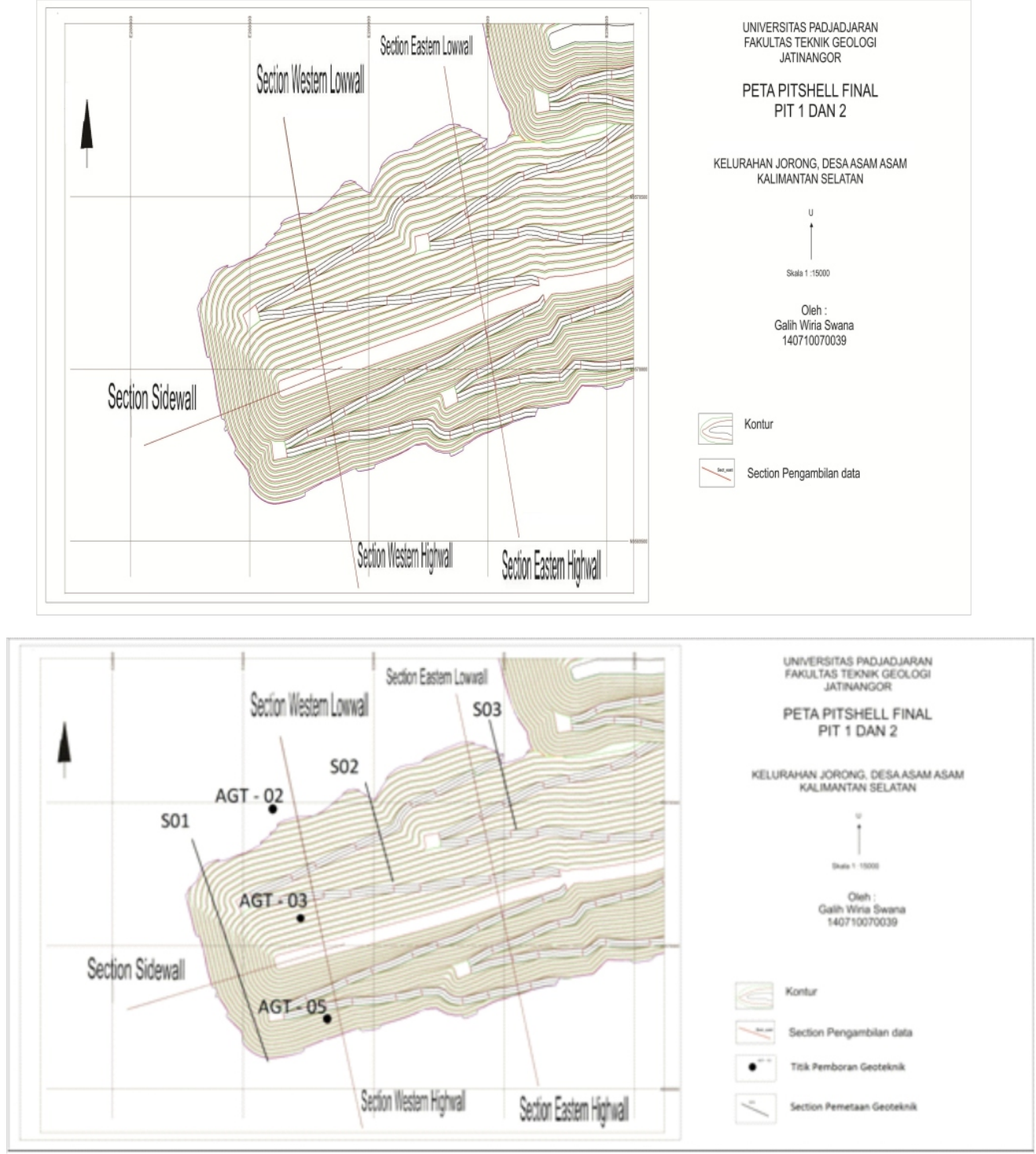

Gambar 2. Posisi lereng di daerah penelitian, titik pengeboran geoteknik, section pemetaan geoteknik dan section yang akan dianalisis 
dari daerah penelitian dan hasil penghitungan pada software Roclab 1.0 diperoleh sifat fisik dan mekanik batuan seperti pada tabel 1 .

Penulis membagi bahasan menjadi 5 bagian berdasarkan posisi lerengnya yaitu Sidewall, Western Lowwall, Western Highwall, Eastern Lowwall, dan Eastern Highwall. Posisi lereng pada daerah penelitian digambarkan pada peta Gambar 2.

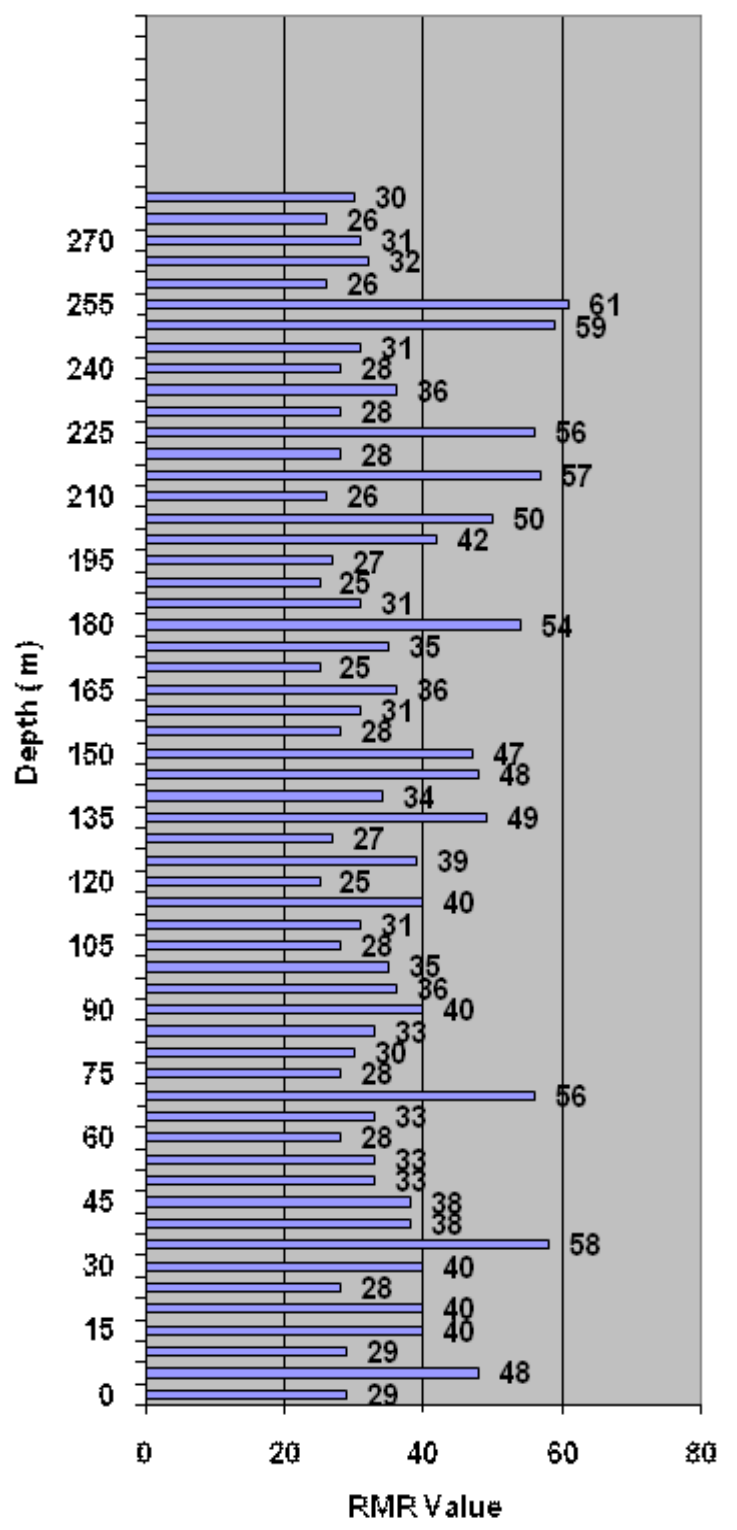

\section{Geomekanik Batuan Sidewall}

Sidewall adalah lereng penghubung lereng Highwall dan Lowwall. Lereng sidewall memiliki arah kemiringan relatif sejajar terhadap arah jurus perlapisan batuan.

Data $R M R$ diperoleh dari pemetaan geomekanik pada section S01. Kisaran RMR pada section Sidewall berkisar antara 25 59 (Gambar 3) yang termasuk kelas massa

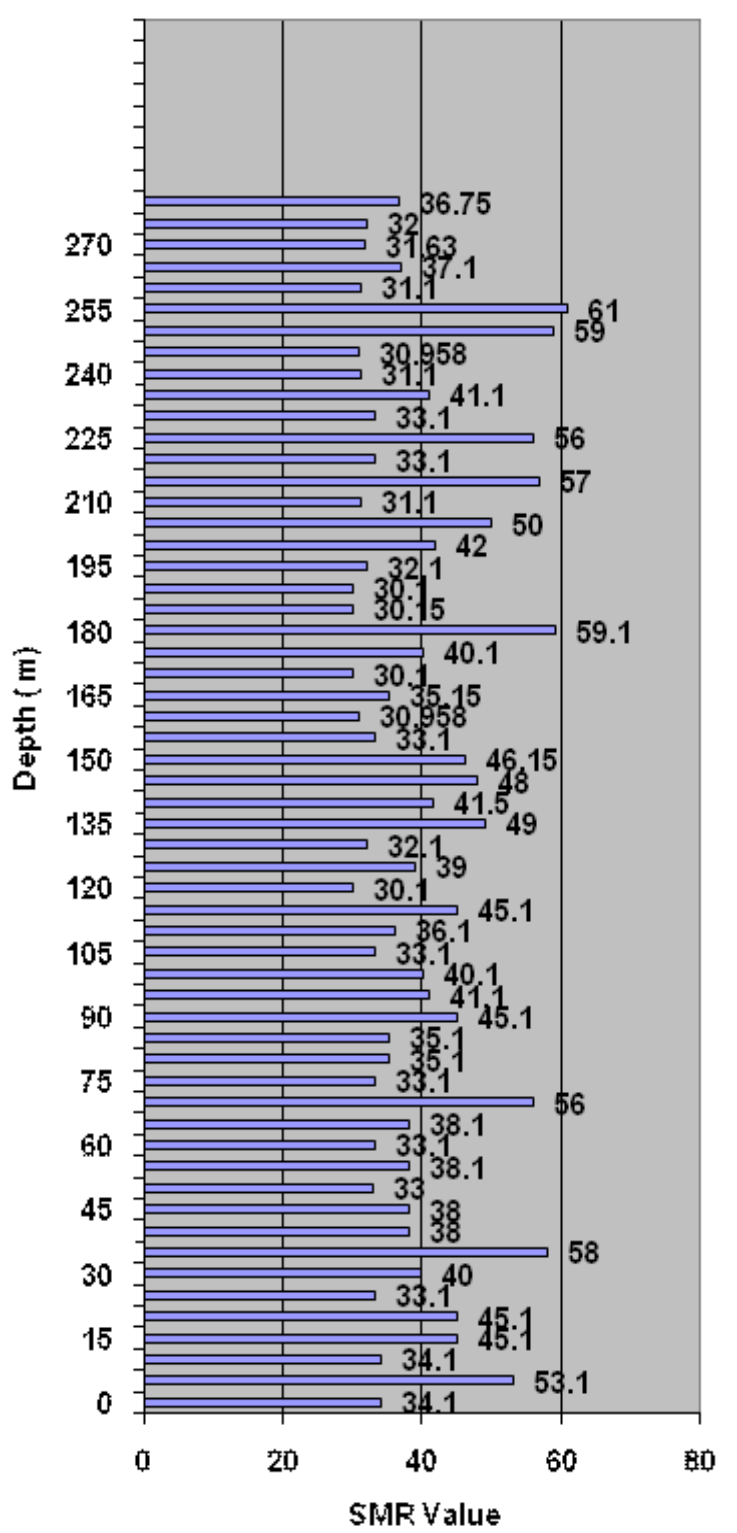

Gambar 3. Rekapitulasi data RMR dan SMR pada section S01 berbanding terhadap kedalaman 
Tabel 2.

Geometri lereng pada section Sidewall

\begin{tabular}{|l|l|l|l|l|l|}
\hline \multicolumn{1}{|c|}{ Sidewall } & $\begin{array}{c}\text { Overall } \\
\text { slope }\end{array}$ & $\begin{array}{c}\text { Jumlah } \\
\text { Undak an }\end{array}$ & $\begin{array}{c}\text { Perbandingan } \\
\text { bench } \\
\text { H orizontal } \\
\text { :V ertikal }\end{array}$ & $\begin{array}{c}\text { Lebar } \\
\text { Berm }\end{array}$ & $\begin{array}{l}\text { Individual } \\
\text { slope }\end{array}$ \\
\hline Rata - rata SMR & $39.67^{0}$ & 16 & $6: 10$ & $7.62 \mathrm{~m}$ & $62.8^{0}$ \\
\hline SMR terkecil & $30.1^{\circ}$ & 16 & $7: 10$ & $9.52 \mathrm{~m}$ & $53^{\circ}$ \\
\hline $\begin{array}{l}\text { Desain Final Lereng } \\
\text { sebelumnya }\end{array}$ & $34^{0}$ & 16 & $7: 10$ & $9.50 \mathrm{~m}$ & $59^{\circ}$ \\
\hline
\end{tabular}

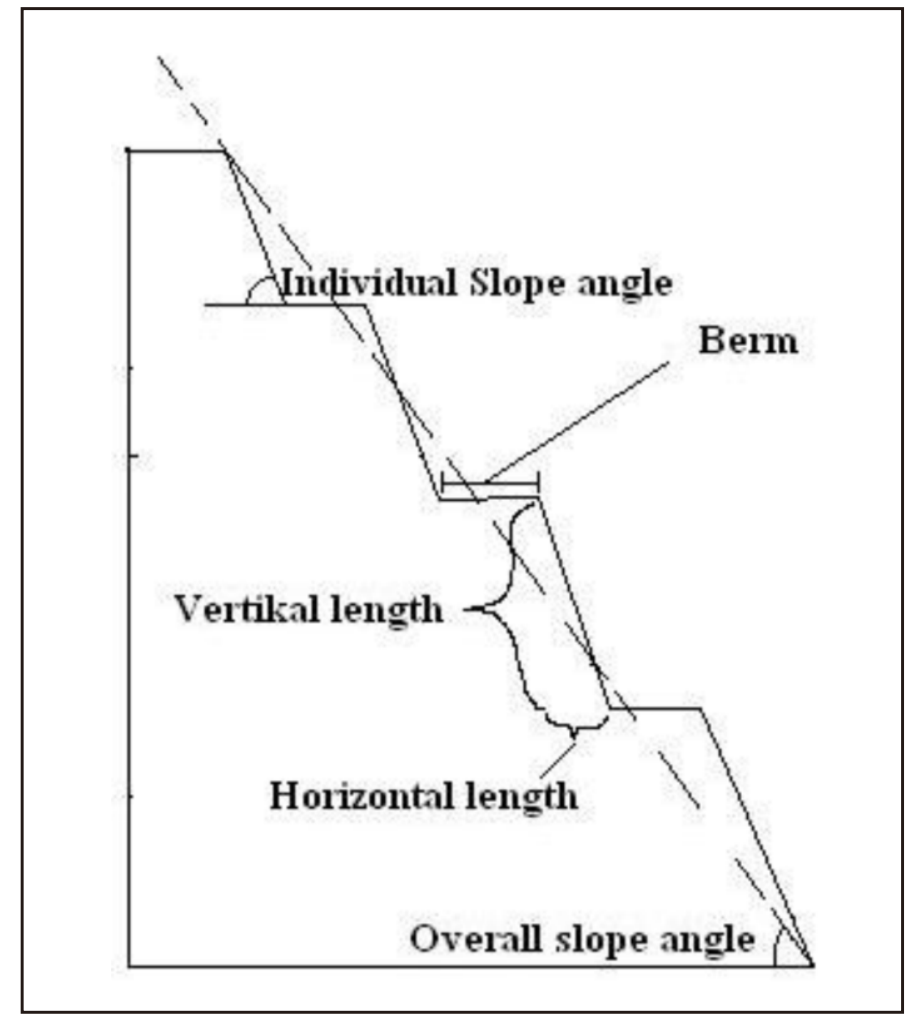

Gambar 4.Parameter-parameter dalam geometri lereng tambang

Tabel 3.

Hasil Analisis kestabilan lereng pada lereng Sidewall

\begin{tabular}{|l|l|l|l|l|}
\hline \multirow{2}{*}{ Sidewall } & \multirow{2}{*}{$\begin{array}{c}\text { Overall } \\
\text { slope }\end{array}$} & \multicolumn{3}{c|}{ FS } \\
\cline { 3 - 5 } & & Non-saturated & Saturated & Saturated+Seismic Load \\
\hline Rata - rata SMR & $39.67^{0}$ & 1.882 & 1.303 & 1.282 \\
\hline SMR terkecil & $30.1^{0}$ & 2.632 & 1.885 & 1.841 \\
\hline $\begin{array}{l}\text { Desain Final Lereng } \\
\text { sebelumnya }\end{array}$ & $34^{0}$ & 2.158 & 1.525 & 1.489 \\
\hline
\end{tabular}


batuan kelas III dan IV sebagai nilai $R M R$ terkecil atau poor rock.

Nilai SMR berkisar antara $30.1^{\circ}-59^{\circ}$ (Gambar 3) dan untuk simulasi digunakan nilai rata - rata dan nilai SMR terkecil. Tabel 2 adalah geometri lereng yang akan dilakukan simulasi dan Parameter dalam lereng di atas bisa kita ketahui dalam sketsa pada gambar 4.

Tabel 3 menggambarkan bahwa semakin besar sudut overall slope yang dibentuk maka semakin kecil nilai FS yang dihasilkan. Hal ini berlaku untuk semua simulasi yaitu pada kondisi kering (nonsaturated), pada kondisi jenuh (saturated), dan jenuh dengan pengaruh gempa (seismic load).

Berdasarkan hasil simulasi di atas dapat disimpulkan bahwa untuk desain final lereng pada section sidewall akan stabil menggunakan overall slope angle sebesar $39,67^{\circ}$

Hasil simulasi pada sudut overall slope yang dibentuk dari nilai rata - rata SMR pada Sidewall dapat dilihat pada Gambar 5.

\section{Western Lowwall}

Lowwall adalah lereng landai yang arah kemiringan lerengnya searah dengan arah kemiringan (dip) perlapisan batuan.

Nilai RMR pada Western Lowwall diperoleh dari hasil korelasi data bor AGT 02 dan AGT - 03, dengan RMR berkisar antara 20 - 55 (Gambar 6) sehingga massa batuan ada pada kelas III dan V. Pada kelas massa batuan III atau fair rock umumnya ialah Mudstone dan Batubara dan pada kelas massa batuan $\mathrm{V}$ atau very poor rock.

Pada section ini diperoleh nilai SMR berkisar antara $20^{\circ}-55^{\circ}$ (Gambar 7) dan rata - rata SMR sebesar $38,2^{\circ}$, sedangkan untuk simulasi digunakan nilai rata - rata dan nilai SMR terkecil.

Tabel 4 dan 5 memberi gambaran bahwa semakin besar sudut overall slope yang dibentuk maka semakin kecil nilai $F S$ yang dihasilkan. Hal ini berlaku untuk semua simulasi yaitu pada kondisi kering, pada kondisi jenuh, dan jenuh dengan pengaruh gempa.

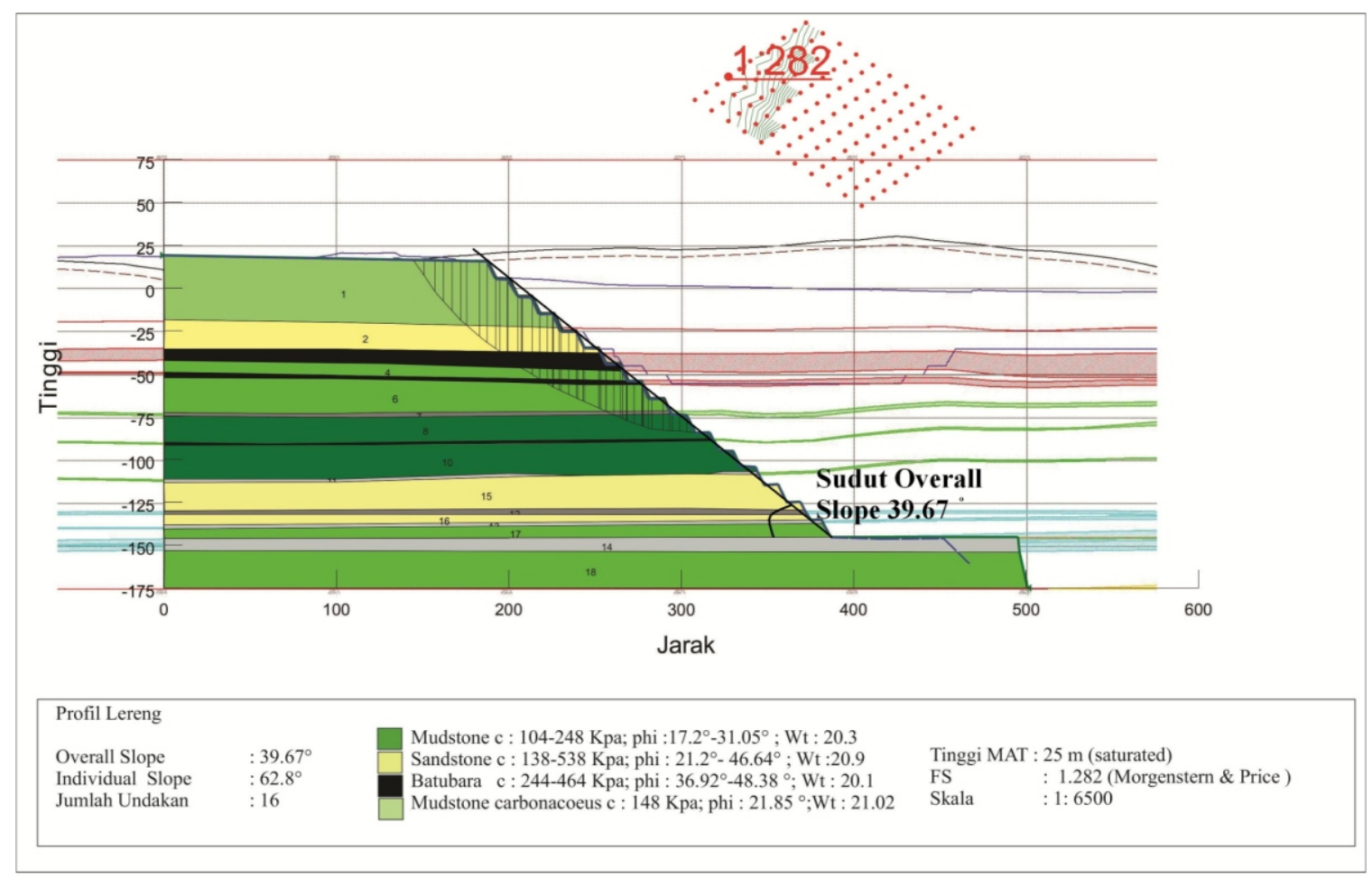

Gambar 5. Simulasi desain lereng final pada section Sidewall 

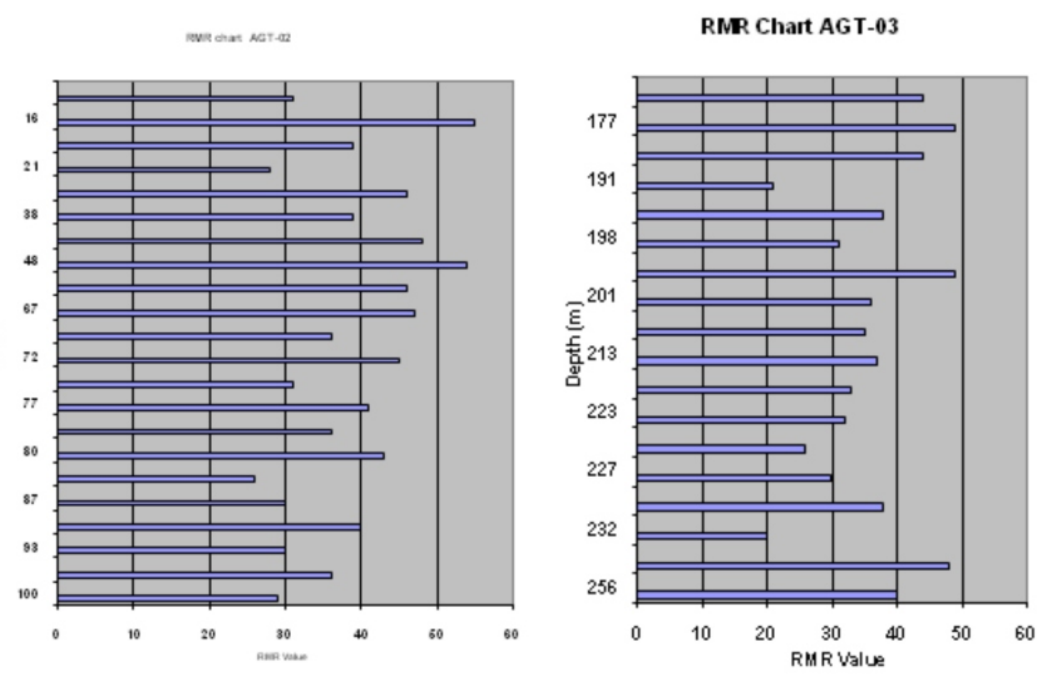

Gambar 6. Rekapitulasi data RMR pada data bor AGT -02 dan AGT -03 terhadap kedalaman
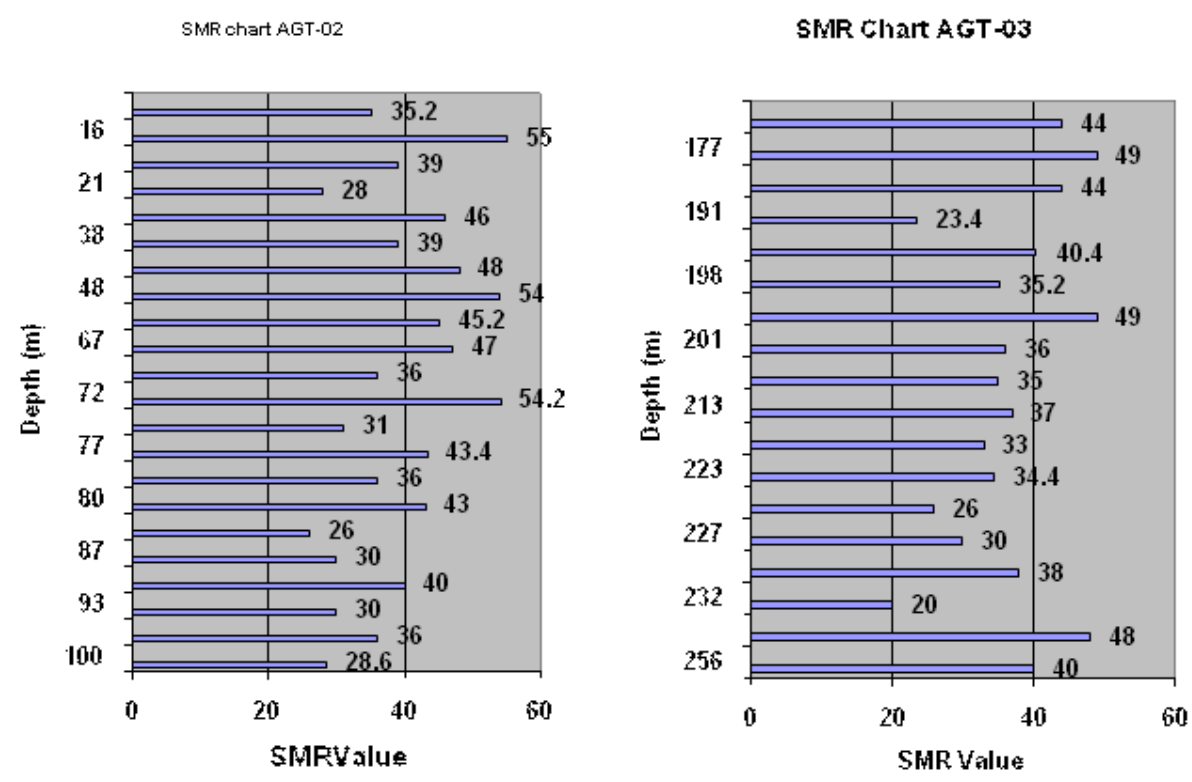

Gambar 7. Rekapitulasi data SMR pada data bor AGT -02 dan AGT -03 terhadap kedalaman

Tabel 4.

Geometri desain lereng final Western Lowwall

\begin{tabular}{|c|c|c|c|c|c|}
\hline Western Lowwall & $\begin{array}{c}\text { Overall } \\
\text { slope }\end{array}$ & \begin{tabular}{|c|} 
Jumlah \\
Undakan
\end{tabular} & $\begin{array}{l}\text { Perbandingan bench } \\
\text { Horizontal : Vertikal }\end{array}$ & $\begin{array}{l}\text { Lebar } \\
\text { Berm }\end{array}$ & $\begin{array}{c}\text { Individual } \\
\text { slope }\end{array}$ \\
\hline Rata- rata SMR & $38.2^{\circ}$ & 17 & $22: 29($ ramp $23 \mathrm{~m})$ & $22 \mathrm{~m}$ & $58^{\circ}$ \\
\hline SMR terkecil & $20^{\circ}$ & 19 & $18: 9(\operatorname{ramp} 48 \mathrm{~m})$ & $5.61 \mathrm{~m}$ & $27.2^{0}$ \\
\hline $\begin{array}{l}\text { Desain Final } \\
\text { Lereng } \\
\text { sebelumnya }\end{array}$ & $23^{0}$ & 20 & $17: 10($ ramp $25 \mathrm{~m})$ & $5.6 \mathrm{~m}$ & $31^{\circ}$ \\
\hline
\end{tabular}


Tabel 5.

Hasil Analisis kestabilan lereng pada lereng Western Lowwall

\begin{tabular}{|l|l|l|l|l|}
\hline \multirow{2}{*}{ Western Lowwall } & \multirow{2}{*}{$\begin{array}{c}\text { Overall } \\
\text { slope }\end{array}$} & \multicolumn{3}{|c|}{ FS } \\
\cline { 3 - 5 } & Non-Saturated & Saturated & Saturated + Seismic Load \\
\hline Rata- rata SMR & $38.2^{0}$ & 0.889 & 0.632 & 0.620 \\
\hline SMR terkecil & $20^{\circ}$ & 1.766 & 1.162 & 1.123 \\
\hline $\begin{array}{l}\text { Desain Final Lereng } \\
\text { sebelumnya }\end{array}$ & $23^{0}$ & 1.438 & 0.961 & 0.929 \\
\hline
\end{tabular}

Berdasarkan hasil simulasi disarankan menggunakan nilai overall slope angle sebesar $20^{\circ}$ pada section Western Lowwall ini, namun diperlukan penurunan muka air tanah sebesar $-75 \mathrm{~m}$ hingga $F S$ naik menjadi 1,274 yang menurut Bowles (1984) lereng berada pada kondisi stabil pada kondisi lereng jenuh dan dalam pengaruh gempa.

Hasil simulasi pada sudut overall slope yang dibentuk dari SMR terkecil pada Western Lowwall, dengan penurunan muka air tanah hingga $-75 \mathrm{~m}$ dapat dilihat pada Gambar 8.

\section{Western Highwall}

Highwall adalah lereng terjal yang arah kemiringan lerengnya berlawanan dengan arah kemiringan (dip) perlapisan batuan.

Nilai RMR pada Western Highwall diperoleh dari hasil korelasi data bor AGT 05 yang berkisar antara $34-71$ (Gambar 9). Dengan nilai $R M R$ tersebut diperoleh massa

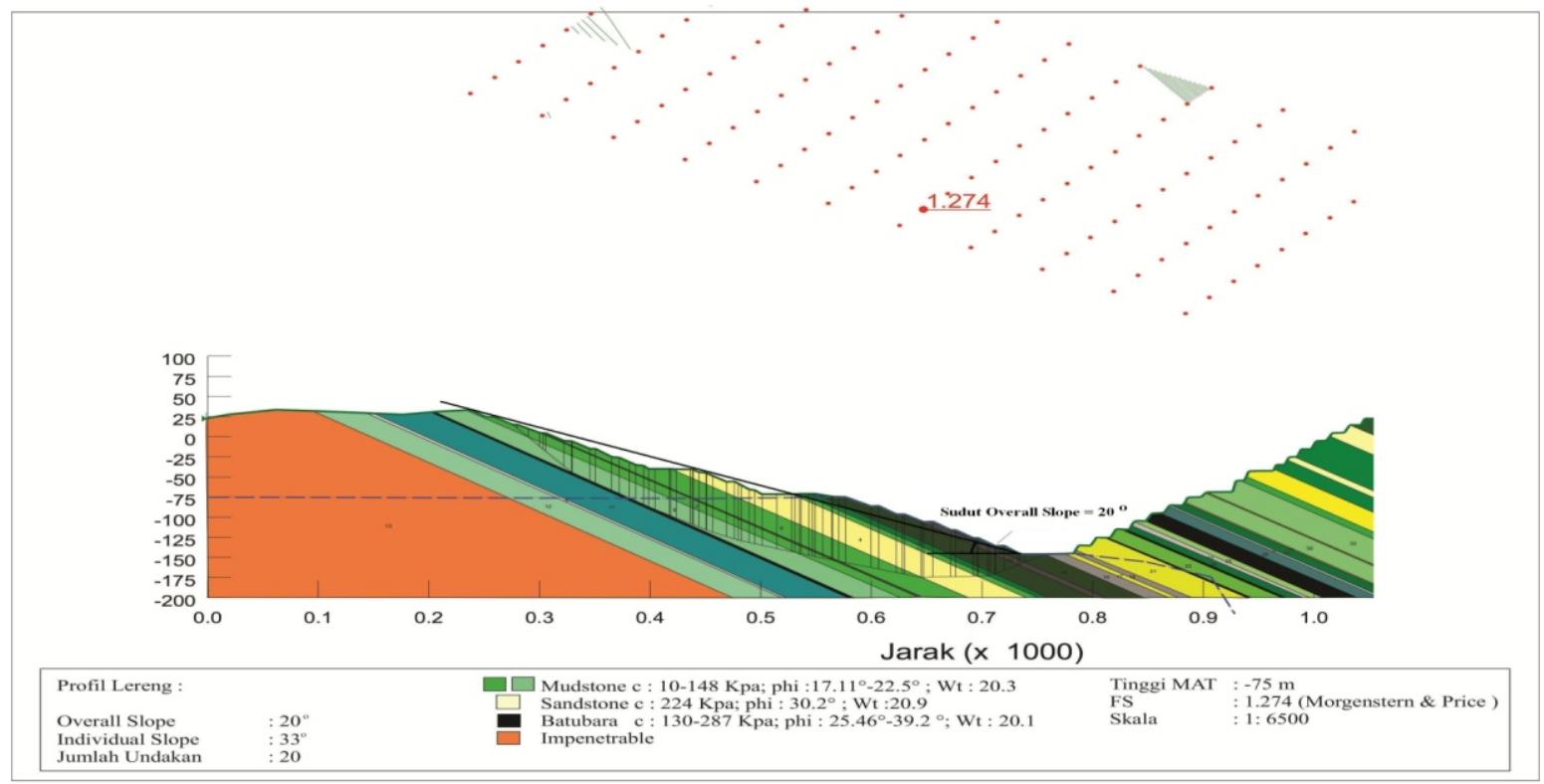

Gambar 8. Simulasi desain lereng final pada section Western Lowwall 


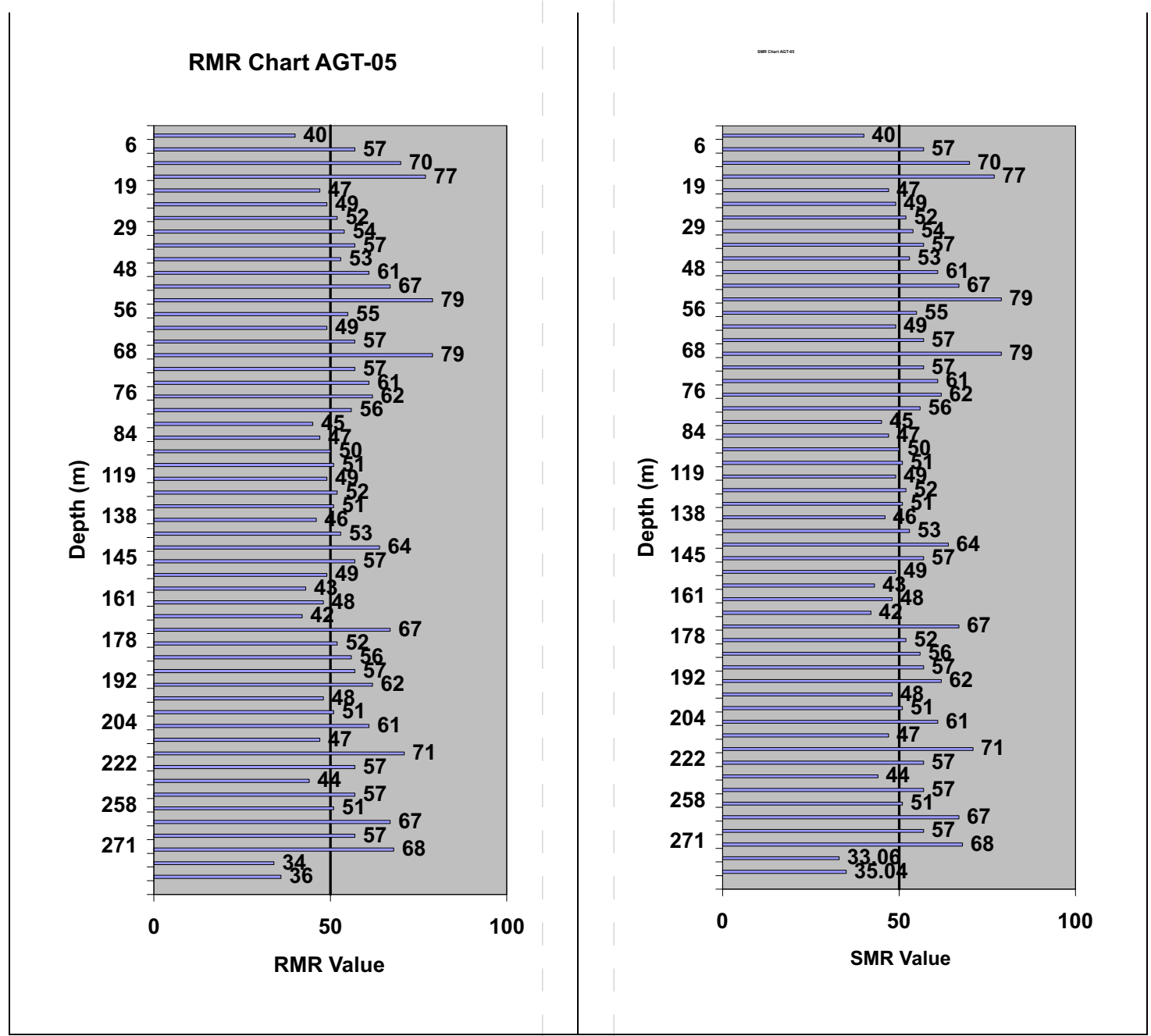

Gambar 9. Rekapitulasi data RMR dan SMR pada data bor AGT -05 terhadap kedalaman

Tabel 6.

Geometri rencana lereng final Western Highwall

\begin{tabular}{|l|l|l|l|l|l|}
\hline Western Highwall & $\begin{array}{c}\text { Overall } \\
\text { slope }\end{array}$ & $\begin{array}{c}\text { Jumlah } \\
\text { Undakan }\end{array}$ & $\begin{array}{c}\text { Perbandingan } \\
\text { bench } \\
\text { H orizontal :V ertikal }\end{array}$ & $\begin{array}{l}\text { Lebar } \\
\text { Berm }\end{array}$ & $\begin{array}{l}\text { Individual } \\
\text { slope }\end{array}$ \\
\hline Rata - rata SMR & $55,03^{0}$ & 20 & $2: 10($ ramp 14 m) & $4,65 \mathrm{~m}$ & $78,3^{\circ}$ \\
\hline SMR terkecil & $33,06^{0}$ & 20 & $4: 10($ ramp 22 m) & $12,07 \mathrm{~m}$ & $63,8^{0}$ \\
\hline $\begin{array}{l}\text { Desain Final } \\
\text { Lereng } \\
\text { sebelumnya }\end{array}$ & $31,9^{\circ}$ & 20 & $5: 8($ ramp 25 m) & $9,42 \mathrm{~m}$ & $62,7^{0}$ \\
\hline
\end{tabular}

Tabel 7.

Hasil analisis kestabilan lereng pada lereng Western Highwall

\begin{tabular}{|l|c|l|l|l|}
\hline \multirow{2}{*}{ Western H ighwall } & Overall & \multicolumn{3}{|c|}{ FS } \\
\cline { 3 - 5 } & slope & Non-saturated & Saturated & Saturated + Seismic Load \\
\hline Rata - rata SMR & $55,03^{0}$ & 1,200 & 0,722 & 0,712 \\
\hline SMR terkecil & $33,06^{0}$ & 1,514 & 1,080 & 1,069 \\
\hline $\begin{array}{l}\text { Desain Final Lereng } \\
\text { sebelumnya }\end{array}$ & $31,9^{0}$ & 1,728 & 1,164 & 1,136 \\
\hline
\end{tabular}


batuan berkisar antara kelas II, III dan IV. Kelas massa batuan II adalah good rock.

Untuk nilai SMR ada pada kisaran antara $33,06^{\circ}-71^{\circ}$ (Gambar 9) dengan rata - rata SMR diperoleh sebesar 55,03 ${ }^{\circ}$. Untuk simulasi digunakan nilai rata - rata dan nilai SMR terkecil dan desain lereng final yang ada sebelumnya sebagai pembanding.

Tabel 6 dan 7 menggambarkan bahwa semakin besar sudut overall slope yang dibentuk maka semakin kecil nilai $F S$ yang dihasilkan.

Berdasarkan keperluan tambang dan untuk mengurangi batuan overburden maka disarankan menggunakan nilai overall slope angle sebesar $33,06^{\circ}$ (geometri pada tabel $6)$. Namun diperlukan penurunan muka air tanah sebesar $-25 \mathrm{~m}$ sehingga nilai $\mathrm{FS}$ ada pada 1,282 pada kondisi jenuh (fully saturated) dan dalam pengaruh seismic load, yang menurut Bowles (1984) nilai FS tersebut ada pada kondisi stabil.

Hasil simulasi pada sudut overall slope yang dibentuk dari SMR terkecil pada Western Highwall, dengan penurunan muka air tanah hingga $-25 \mathrm{~m}$, dapat dilihat pada Gambar 10.

\section{Eastern Lowwall}

RMR pada bagian Eastern Lowwall diperoleh dari hasil korelasi dari pemetaan geomekanik pada S03 dan S02. Pada section ini $R M R$ berkisar antara 20 - 55 (Gambar 11) yang berarti massa batuannya berkisar antara kelas III - V atau ada pada rentang fair rock hingga very poor rock.

Dari gambar diatas diperoleh nilai SMR berkisar antara $20^{\circ}-54,96^{\circ}$ dengan rata rata SMR diperoleh sebesar 39,04\%. Untuk simulasi digunakan nilai rata - rata dan nilai SMR terkecil dan desain lereng final yang ada sebelumnya sebagai pembanding.

Dari tabel diatas bisa disimpulkan bahwa semakin besar sudut overall slope yang dibentuk maka semakin kecil nilai $F S$ yang dihasilkan. Hal ini berlaku untuk semua simulasi yaitu pada kondisi kering (nonsaturated), pada kondisi jenuh (saturated), dan jenuh dengan pengaruh gempa

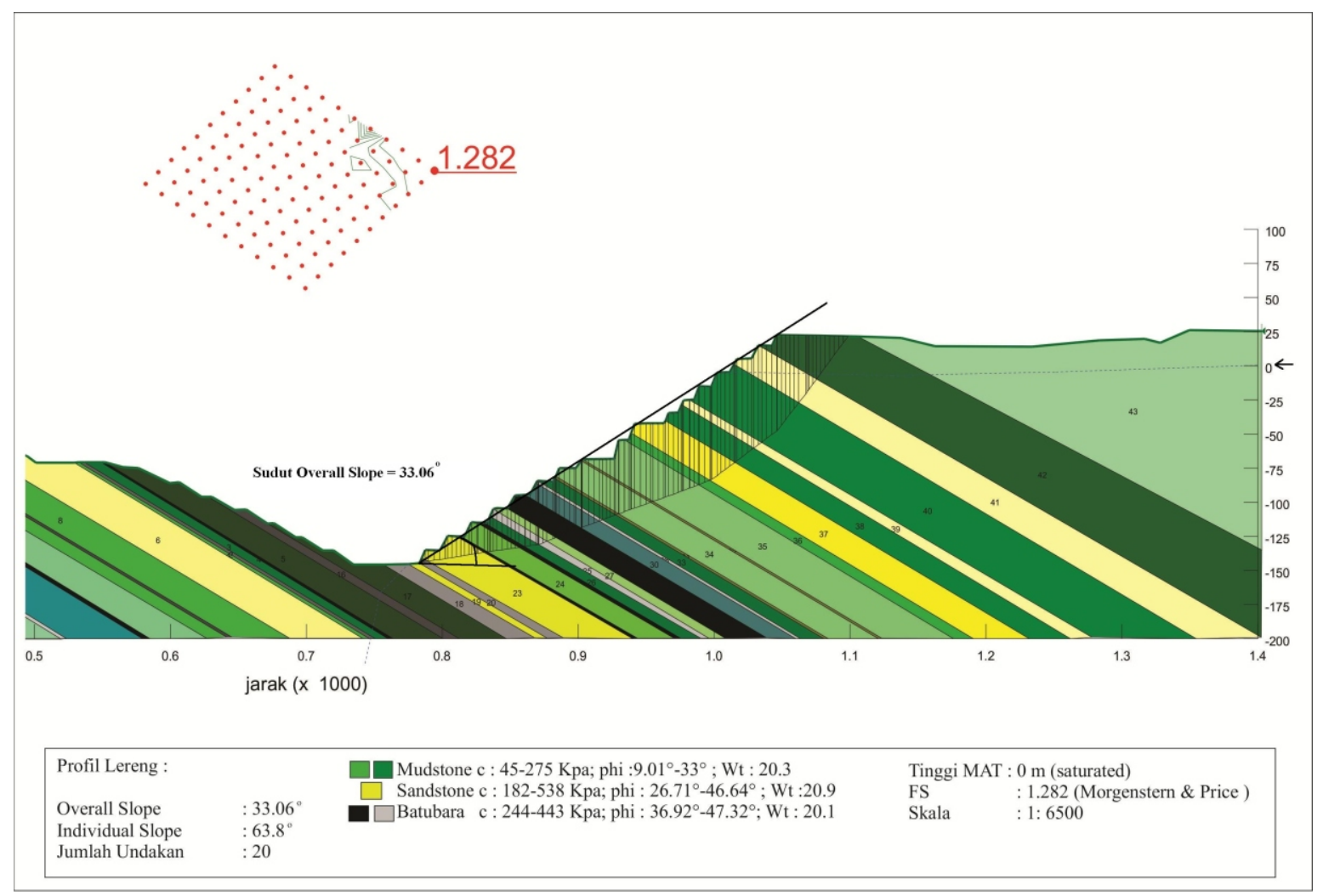

Gambar 10. Simulasi desain lereng final pada section Western Highwall 


\section{MAKALAH ILMIAH}

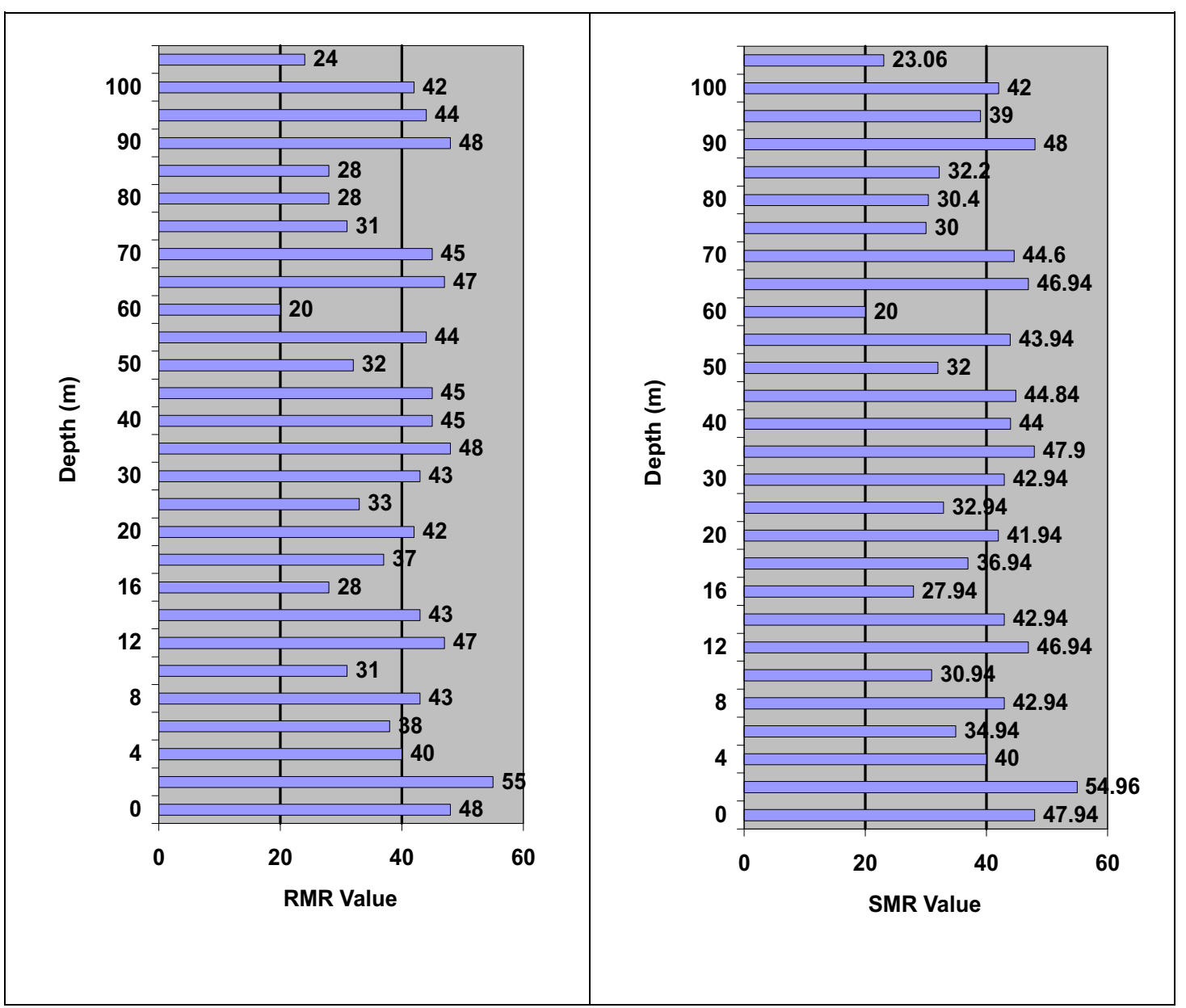

Gambar 11. Rekapitulasi data RMR dan SMR pada data section S02 \& S03 terhadap kedalaman

Tabel 8.

Geometri desain lereng final pada lereng Eastern Lowwall

\begin{tabular}{|l|l|l|l|l|l|}
\hline Eastern Lowwall & $\begin{array}{c}\text { Overall } \\
\text { slope }\end{array}$ & $\begin{array}{c}\text { Jumlah } \\
\text { Undakan }\end{array}$ & $\begin{array}{c}\text { Perbandingan bench } \\
\text { Horizontal : Vertikal }\end{array}$ & $\begin{array}{c}\text { Lebar } \\
\text { Berm }\end{array}$ & $\begin{array}{c}\text { Individual } \\
\text { slope }\end{array}$ \\
\hline Rata - rata SMR & $39,04^{\circ}$ & 5 & $13: 18($ ramp 22 m) & $22 \mathrm{~m}$ & $52^{\circ}$ \\
\hline SMR terkecil & $20^{\circ}$ & 20 & $16: 9($ ramp $35 \mathrm{~m})$ & $4,94 \mathrm{~m}$ & $29^{\circ}$ \\
\hline $\begin{array}{l}\text { Desain Final Lereng } \\
\text { sebelumnya }\end{array}$ & $22^{\circ}$ & 21 & $16: 9($ ramp $25 \mathrm{~m})$ & $4,58 \mathrm{~m}$ & $30,8^{\circ}$ \\
\hline
\end{tabular}

Tabel 9.

Hasil analisis kestabilan lereng pada lereng Eastern Lowwall

\begin{tabular}{|l|l|l|l|l|}
\hline \multirow{2}{*}{ Eastern Lowwall } & \multirow{2}{*}{$\begin{array}{c}\text { Overall } \\
\text { slope }\end{array}$} & \multicolumn{3}{c|}{ FS } \\
\cline { 3 - 6 } & $3^{2}, 04^{0}$ & 0,977 & 0,652 & 0,641 \\
\hline Rata- rata SMR & $20^{\circ}$ & 1,776 & 1,288 & 1,254 \\
\hline SMR terkecil & $22^{\circ}$ & 1,735 & 1,216 & 1,185 \\
\hline $\begin{array}{l}\text { Desain Final Lereng } \\
\text { sebelumnya }\end{array}$ & & & & \\
\hline
\end{tabular}




\section{MAKALAH ILMIAH}

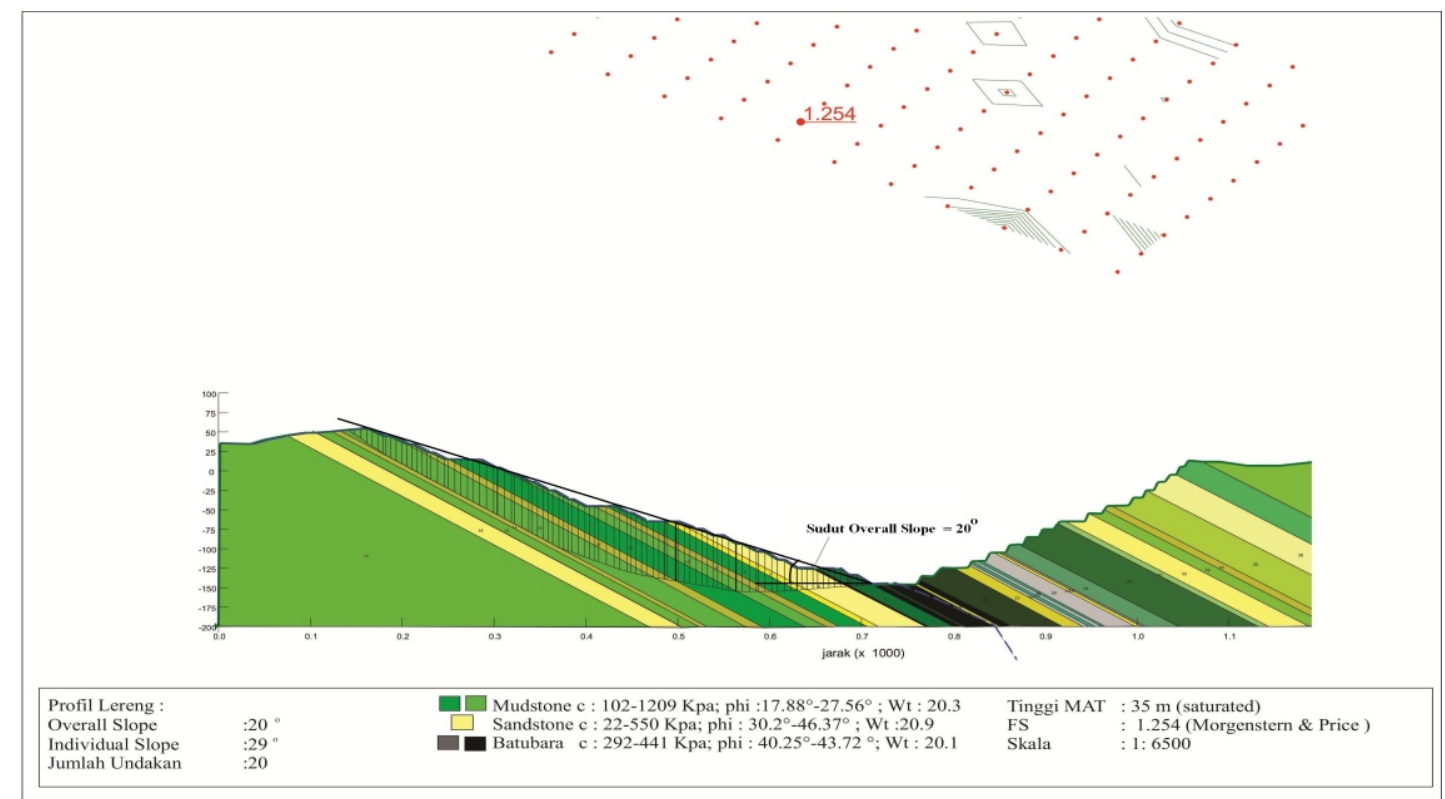

Gambar 12. Simulasi desain lereng final pada section Eastern Lowwall

(seismic load). Untuk mengurangi batuan overburden maka disarankan menggunakan nilai overall slope angle sebesar $20^{\circ}$.

Hasil simulasi pada sudut overall slope yang dibentuk dari SMR terkecil pada lereng Eastern Lowwall (Gambar 12).

\section{Eastern Highwall}

$R M R$ pada lereng Eastern highwall diperoleh dari hasil korelasi pemetaan geomekanik pada S03 dan data bor AGT-05, sehingga diperoleh $R M R$ ada pada kisaran 29 -79 (Gambar 13) atau termasuk kelas

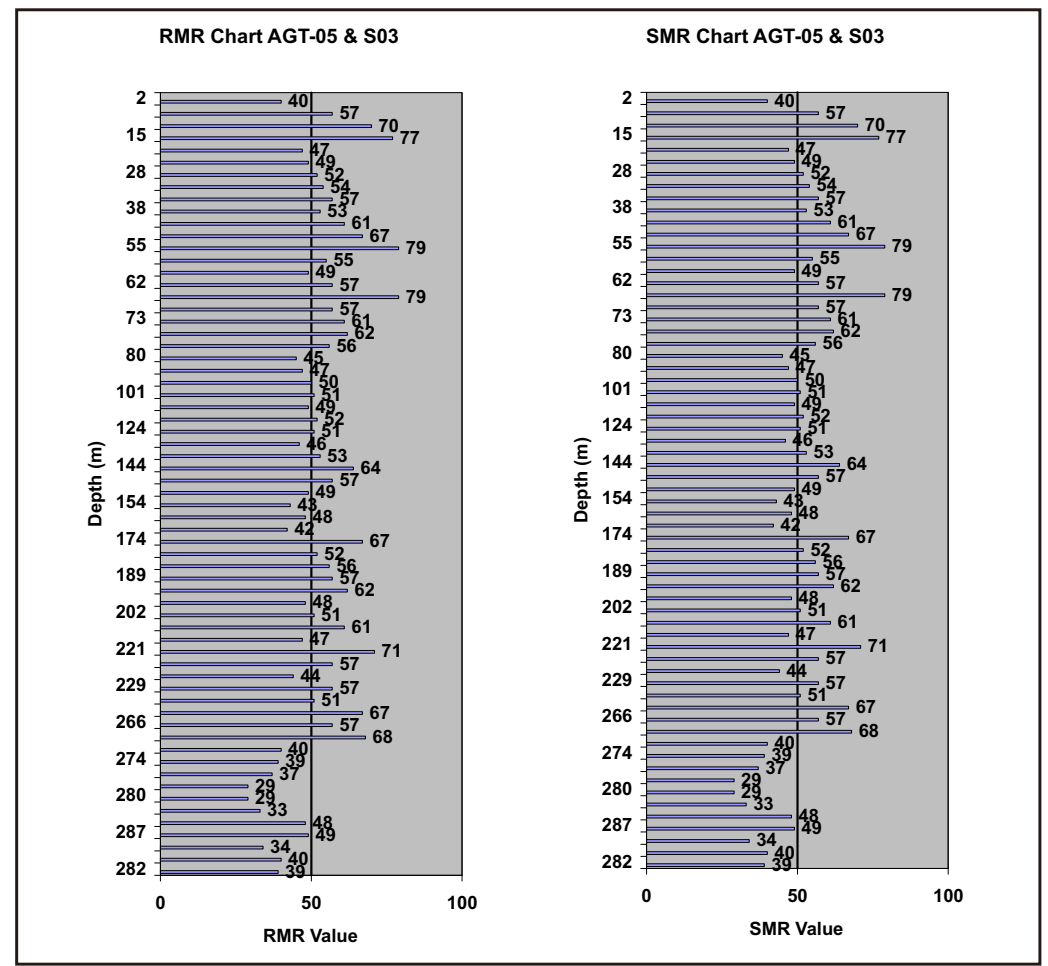

Gambar 13. Rekapitulasi data RMR dan SMR pada data section AGT 05 \& S03 terhadap kedalaman 


\section{MAKALAH ILMIAH}

massa batuan II, III, dan IV. Kelas massa batuan II atau good rock umumnya berupa Mudstone dan batupasir ataupun muddy sandstone yang bersifat masif dan memiliki sedikit diskontinuitas. Sedangkan untuk kelas massa batuan III atau fair rock berupa batubara dan batupasir.

Berdasarkan gambar 13 diperoleh nilai $S M R$ berkisar antara $29^{\circ}-79^{\circ}$ dengan rata rata $S M R$ sebesar $52,75^{\circ}$. Untuk simulasi digunakan nilai rata - rata dan nilai $S M R$ terkecil dan desain lereng final yang ada sebelumnya sebagai pembanding.

Berdasarkan Tabel 10 dan 11 dapat disimpulkan bahwa semakin besar sudut overall slope yang dibentuk maka semakin kecil nilai safety factor yang dihasilkan. Dilihat dari keperluan tambang dan untuk mengurangi batuan overburden disarankan menggunakan nilai overall slope angle sebesar $29^{\circ}$.

Hasil simulasi pada sudut overall slope yang dibentuk dari SMR terkecil pada Eastern Highwall dapat dilihat pada Gambar 14.

Berdasarkan grafik perbandingan $R M R$ terhadap kedalaman pada tiap section, memperlihatkan bahwa nilai $R M R$ bervariasi dan tidak bergantung terhadap kedalaman karena daerah penelitian disusun oleh material batuan sedimen yang tidak homogen.

Dari hasil simulasi di atas dapat direkomendasikan geometri lereng untuk tiap section dapat dilihat pada Tabel 12.

Tabel 10.

Geometri desain lereng final pada lereng Eastern Highwall

\begin{tabular}{|l|l|l|l|l|l|}
\hline Eastern highwall & $\begin{array}{c}\text { Overall } \\
\text { slope }\end{array}$ & $\begin{array}{c}\text { Jumlah } \\
\text { Undakan }\end{array}$ & $\begin{array}{c}\text { Perbandingan bench } \\
\text { H orizontal :V ertikal }\end{array}$ & $\begin{array}{c}\text { Lebar } \\
\text { Berm }\end{array}$ & $\begin{array}{c}\text { Individual } \\
\text { slope }\end{array}$ \\
\hline Rata - rata SMR & $52^{0}$ & 17 & $1: 9($ ramp 14 m) & $18 \mathrm{~m}$ & $80,2^{0}$ \\
\hline SMR terkecil & $29^{\circ}$ & 18 & $4: 9($ ramp 27 m) & $14,55 \mathrm{~m}$ & $52,1^{0}$ \\
\hline $\begin{array}{l}\text { Desain Final Lereng } \\
\text { sebelumnya }\end{array}$ & $30^{\circ}$ & 18 & $5: 9($ ramp $26 \mathrm{~m})$ & $8,06 \mathrm{~m}$ & $61,2^{0}$ \\
\hline
\end{tabular}

Tabel 11.

Hasil analisis kestabilan lereng pada lereng Eastern Highwall

\begin{tabular}{|l|l|l|l|l|}
\hline \multirow{2}{*}{ Eastern highwall } & \multirow{2}{*}{$\begin{array}{c}\text { Overall } \\
\text { slope }\end{array}$} & \multicolumn{3}{|c|}{ FS } \\
\cline { 3 - 5 } & & Non saturated & Saturated & Saturated + Seismic Load \\
\hline Rata - rata SMR & $52^{\circ}$ & 1,272 & 0,709 & 0,697 \\
\hline SMR terkecil & $29^{\circ}$ & 1,941 & 1,294 & 1,264 \\
\hline $\begin{array}{l}\text { Desain Final Lereng } \\
\text { sebelumnya }\end{array}$ & $30^{\circ}$ & 1,890 & 1,230 & 1,205 \\
\hline
\end{tabular}




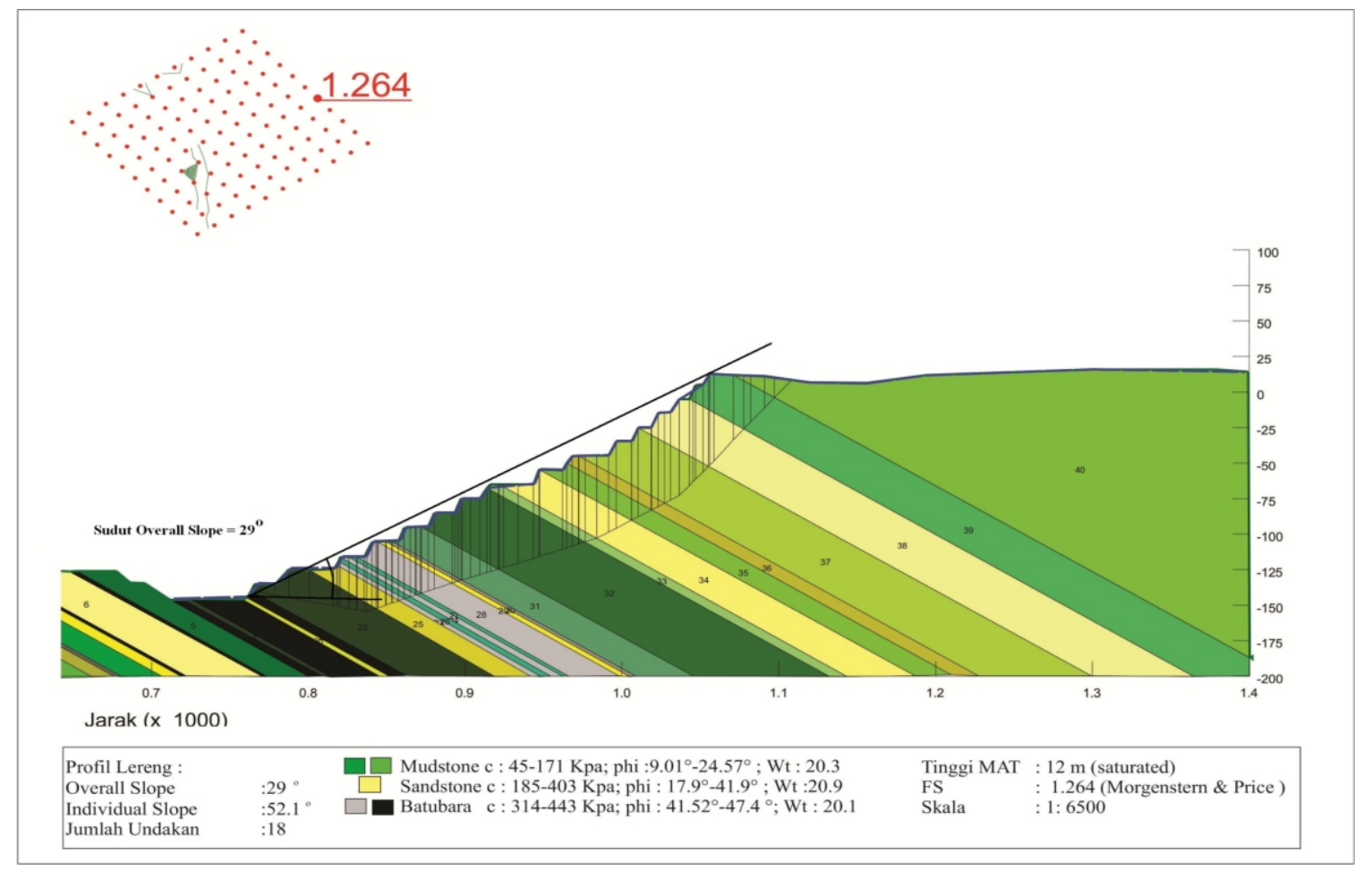

Gambar 14. Simulasi desain lereng final pada section Eastern Highwall

Tabel 12.

Rekomendasi geometri lereng untuk tiap section

\begin{tabular}{|l|l|l|l|l|l|}
\hline \multicolumn{1}{|c|}{ Section } & Overall Slope & $\begin{array}{c}\text { Jumlah } \\
\text { Undakan }\end{array}$ & $\begin{array}{c}\text { Perbandingan } \\
\mathbf{H}: \text { V }\end{array}$ & $\begin{array}{c}\text { Individual } \\
\text { Slope }\end{array}$ & $\begin{array}{c}\text { Penurunan } \\
\text { water table }\end{array}$ \\
\hline Sidewall & $39,67^{\circ}$ & 16 & $6: 10$ & $62,8^{0}$ & - \\
\hline $\begin{array}{l}\text { Western } \\
\text { Lowwall }\end{array}$ & $20^{\circ}$ & 19 & $18: 9($ ramp $48 \mathrm{~m})$ & $27,2^{\circ}$ & hingga $-75 \mathrm{~m}$ \\
\hline $\begin{array}{l}\text { Western } \\
\text { Highwall }\end{array}$ & $33,06^{\circ}$ & 20 & $4: 10($ ramp $25 \mathrm{~m})$ & $63,8^{\circ}$ & hingga $-25 \mathrm{~m}$ \\
\hline $\begin{array}{l}\text { Eastern } \\
\text { Lowwall }\end{array}$ & $20^{\circ}$ & 20 & $16: 9($ ramp $35 \mathrm{~m})$ & $29^{\circ}$ & - \\
\hline $\begin{array}{l}\text { Eastern } \\
\text { Highwall }\end{array}$ & $29^{\circ}$ & 18 & $4: 9($ ramp 27 m) & $52,1^{\circ}$ & - \\
\hline
\end{tabular}

\section{KESIMPULAN DAN SARAN}

Dari hasil simulasi kestabilan lereng, pada lereng yang dibentuk dari nilai $S M R$ diperoleh kesimpulan bahwa tidak semua lereng yang dihitung dari nilai SMR memberikan jaminan bahwa lereng tersebut akan stabil. Namun dari grafik hubungan nilai FS dengan overall slope angle bisa diambil kesimpulan bahwa semakin besar sudut lereng maka semakin kecil nilai FS, sehingga lereng pun semakin berada pada kondisi tidak stabil.

Pada lereng Sidewall, Eastern Lowwall, dan Eastern Highwall, lereng umumnya stabil dengan menggunakan nilai $S M R$ terkecil. Namun pada section lereng Western Lowwall dan Western Highwall, lereng akan stabil jika sudut lereng yang dibentuk dibawah nilai sudut SMR terkecil 
atau diperlukan penurunan muka air tanah hingga kedalaman $-75 \mathrm{~m}$ pada lereng Western Lowwall, dan sedalam -25 m pada lereng Western Highwall agar nilai FS nya ada pada kondisi stabil.

Penelitian Ianjutan disarankan dilakukan pada saat musim hujan sehingga didapat kondisi batuan yang jenuh air (Fully Saturated).

\section{UCAPAN TERIMA KASIH}

Penulis mengucapkan terima kasih kepada berbagai pihak yang telah membantu selama proses penelitian ini khususnya kepada Endang Wawan, ST., yang telah memberi izin untuk melakukan penelitian juga kepada Prof. Dr. Ir. Febri Hirnawan atas aneka saran yang diberikan dalam penulisan makalah ini.

\section{DAFTAR PUSTAKA}

Bieniawski, Z.T. 1989. "Engineering Rock Mass Clasification : A Complete Manual for Engineers and Geologist in Mining, Civil, and Petroleum Engineering". Canada : John Wiley \& Sons Inc.

Bowles, E., Joseph. 1984. Physical and Geotechnical Properties of Soil: Second Edition. New York : McGraw-Hill. Hal. 525-548

Eberhardt, E. 2005. Geotechnical Engineering Practice \& Design : Lecture 7 : Limit Equilibrium. EOSC.

Hirnawan, F. 2009. Pendidikan dan Pelatihan Analisis Kestabilan Lereng: Metode RMR dan SMR. Bandung: Pusdiklat Geologi.

Hoek, E., Carranza-Torres, C., dan Corkum, B. 2002. Hoek-Brown Failure Criterion, 2002 Edition. Toronto: Dept. of Civil Engineering, University of Toronto.

Hoek, E., and Marinos, P. 2007. A Brief History of the Development of the Hoek Brown Failure Criterion, Brazilian Journal of Soil and Rocks, No. 2

Krahn, J. 2004. Stability Modelling with Slope/W an Engineering Methodology, Geo_Slope/W. Canada International Ltd.

Romana, M.R. 1993. A Geomechanical Classification for Slopes: Slope Mass Rating. Spain: Universidad Politécnica Valencia.

Sikumbang N. dan Heryanto R., 1994: Peta Geologi Lembar Banjarmasin 1712, Kalimantan, sekala 1:250.000, Pusat Penelitian dan Pengembangan Geologi (P3G) Bandung.

Sjoberg, J. 1997. Estimating Rock Mass Strength Using the Hoek-Brown Failure Criterion and Rock Mass Classification. Sweden : Lulea University of Technology Division of Rock Mechanics. 